\title{
Preliminary Siting Criteria for the Proposed Mixed and Low-Level Waste Treatment Facility at the Idaho National Engineering Laboratory
}

Mary Jorgenson-Waters

Published September 1992

Idaho National Engineering Laboratory

EG\&G Idaho, Inc.

idaho Falls, Idaho 83415 


\begin{abstract}
The Mixed and Low-Level Waste Treatment Facility project was established in 1991 by the U.S. Department of Energy Idaho Field Office. This facility will provide treatment capabilities for Idaho National Engineering Laboratory (INEL) low-level mixed waste and low-level waste. This report identifies the siting requirements imposed on facilities that treat and store these waste types by Federal and State regulatory agencies and the U.S. Department of Energy. Site selection criteria based on cost, environmental, health and safety, archeological, geological and service, and support requirements are presented. These criteria will be used to recommend alternative sites for the new facility. The National Environmental Policy Act process will then be invoked to evaluate the alternatives and the alternative sites and make a final site determination.
\end{abstract}




\section{CONTENTS}

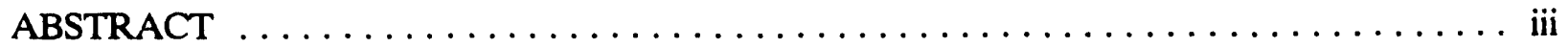

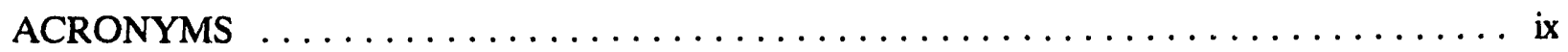

1. INTRODUCTION $\ldots \ldots \ldots \ldots \ldots \ldots \ldots \ldots \ldots \ldots \ldots \ldots \ldots \ldots \ldots \ldots \ldots \ldots \ldots$

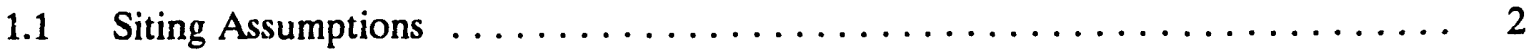

2. RECOMMENDED APPROACH FOR SITE SELECTION $\ldots \ldots \ldots \ldots \ldots \ldots \ldots$

3. ENVIRONMENTAL REGULATIONS $\ldots \ldots \ldots \ldots \ldots \ldots \ldots \ldots \ldots \ldots \ldots$

3.1 Resource Conservation and Recovery Act (42 U.S.C. 6921 et seq.) . . . . . . . 7

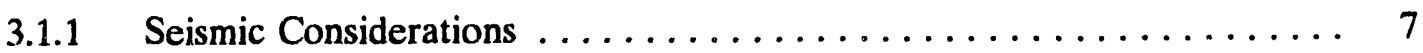

3.1.2 Floodplains .......................... 7

3.1.3 Salt Dome Formations, Salt Bed Formations, Underground Mines,

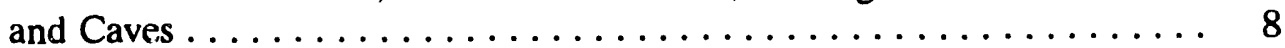

3.2 Wild and Scenic Rivers Act (16 U.S.C. 1273 et seq.) $\ldots \ldots \ldots \ldots \ldots \ldots \ldots$

3.3 National Historic Preservation Act of 1966 (16 U.S.C. 470 et seq.) $\ldots \ldots \ldots \ldots$

3.4 Endangered Species Act of 1973 (16 U.S.C. 1531 et seq.) $\ldots \ldots \ldots \ldots \ldots \ldots$

3.5 Fish and Wildlife Coordination Act (16 U.S.C. 661 et seq.) $\ldots \ldots \ldots \ldots \ldots \ldots 9$

3.6 Coastal Zone Management Act (16 U.S.C. 1451 et seq.) $\ldots \ldots \ldots \ldots \ldots \ldots \ldots 9$

3.7 Wilderness Protection Act of 1964 (16 U.S.C. 1131 et seq.) . . . . . . . . . 9

3.8 Toxic Substances Control Act of 1976 (15 U.S.C. 2601 et seq.) . . . . . . . . 10

3.9 Clean Air Act of 1970 (42 U.S.C 7401 et seq.) $\ldots \ldots \ldots \ldots \ldots \ldots \ldots \ldots$

3.10 Wetlands (Executive Order 11990) $\ldots \ldots \ldots \ldots \ldots \ldots \ldots \ldots \ldots \ldots \ldots$

3.11 Floodplains (Executive Order 11988$) \ldots \ldots \ldots \ldots \ldots \ldots \ldots \ldots \ldots \ldots$

3.12 National Environmental Policy Act (42 U.S.C. 4321 et seq.) $\ldots \ldots \ldots \ldots \ldots \ldots 11$

3.13 National Emission Standards for Hazardous Air Pollutants

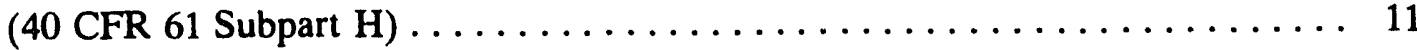

4. DOE ORDER 6430.1A, "GENERAL DESIGN CRITERIA," ENVIRONMENTAL SITING REQUIREMENTS 
4.1 Section 0200, "Site Development" $\ldots \ldots \ldots \ldots \ldots \ldots \ldots \ldots \ldots \ldots \ldots \ldots$

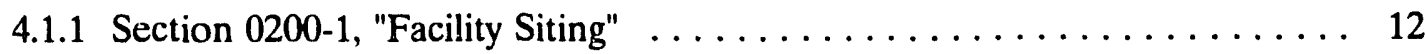

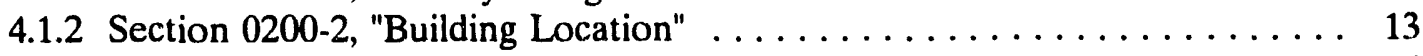

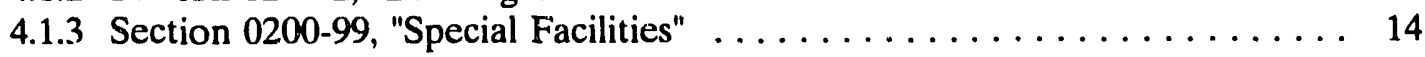

4.2 Section 0285 , "Solid Waste Systems" $\ldots \ldots \ldots \ldots \ldots \ldots \ldots \ldots \ldots \ldots \ldots$

4.2.1 Section 0285-2.2.2, "Environmentally Sensitive Areas" . . . . . . . . . . . 14

4.2.2 Section 0285-2.2.3, "Fault Zones and Karst Terrain" . . . . . . . . . . . . 15

4.2.3 Section 0285-2.2.4, "Cost Effectiveness" . . . . . . . . . . . . . . 15

4.2.4 Section $0285-2.2 .5$, "Sites Traversed by Utilities" . . . . . . . . . . . . 15

4.2.5 Section 0285-2.2.6, "Characteristics and Availability of Soil Cover" . . . . . 15

4.2.6 Section 0285-2.2.7, "Site Access" . . . . . . . . . . . . . . . . . 15

4.2.7 Section 0285-2.2.8, "Effects on Other Facilities" . . . . . . . . . . 15

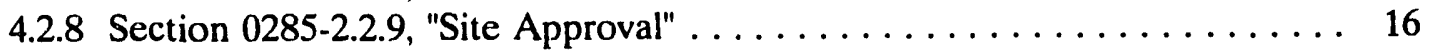

5. IDAHO LAWS AND REGULATIONS $\ldots \ldots \ldots \ldots \ldots \ldots \ldots \ldots \ldots \ldots \ldots$

6. SERVICE AND SUPPORT REQUIREMENTS $\ldots \ldots \ldots \ldots \ldots \ldots \ldots \ldots \ldots \ldots$

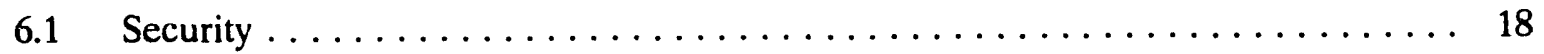

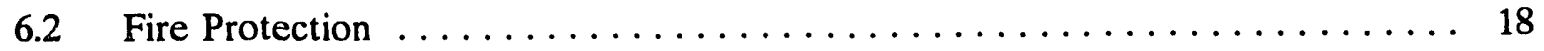

6.3 Occupational Medical $\ldots \ldots \ldots \ldots \ldots \ldots \ldots \ldots \ldots \ldots \ldots \ldots \ldots \ldots$

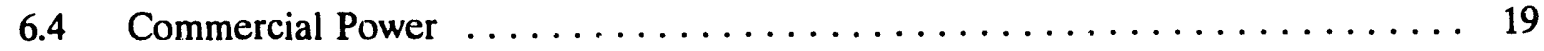

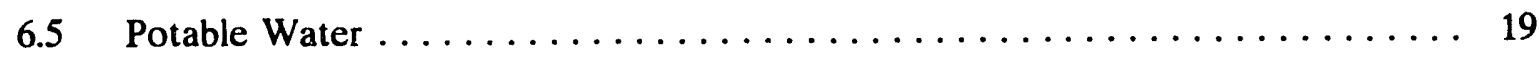

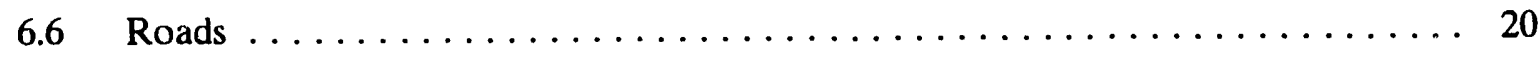

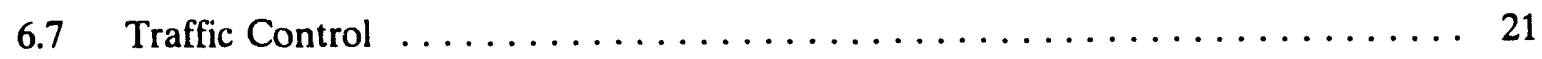

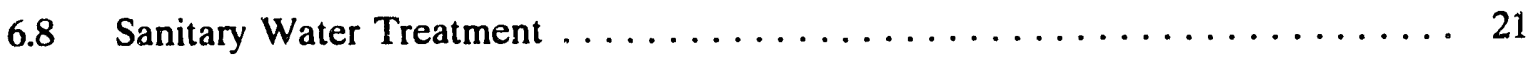

6.9 Generai Service and Support $\ldots \ldots \ldots \ldots \ldots \ldots \ldots \ldots \ldots \ldots \ldots \ldots \ldots \ldots \ldots \ldots \ldots$

7. SITE SELECTION CRITERIA $\ldots \ldots \ldots \ldots \ldots \ldots \ldots \ldots \ldots \ldots \ldots \ldots \ldots \ldots$

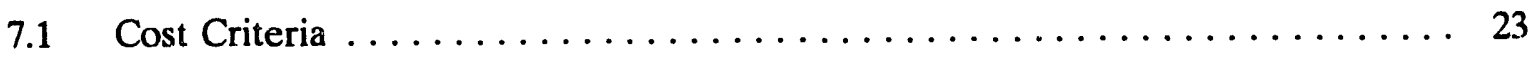

7.2 Service and Support Siting Criteria $\ldots \ldots \ldots \ldots \ldots \ldots \ldots \ldots \ldots \ldots \ldots$

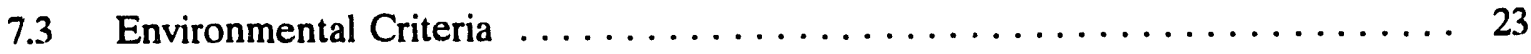

7.4 Archeological Criteria $\ldots \ldots \ldots \ldots \ldots \ldots \ldots \ldots \ldots \ldots \ldots \ldots \ldots \ldots \ldots$

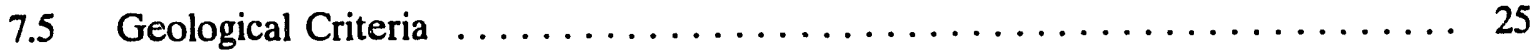




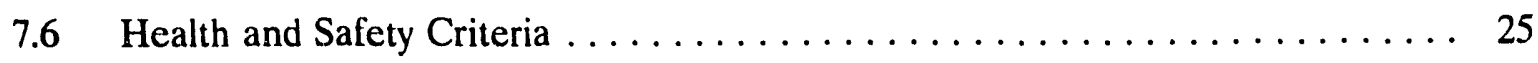

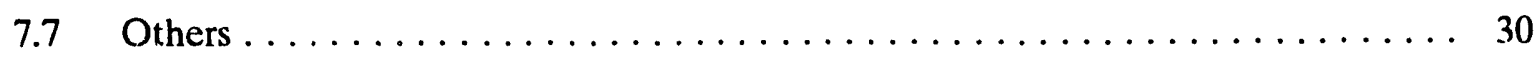

8. SUMMARY AND CONCLUSIONS $\ldots \ldots \ldots \ldots \ldots \ldots \ldots \ldots \ldots \ldots \ldots \ldots$

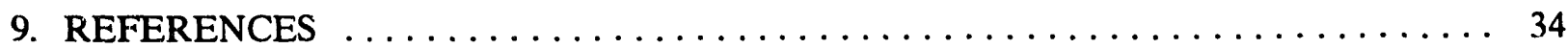

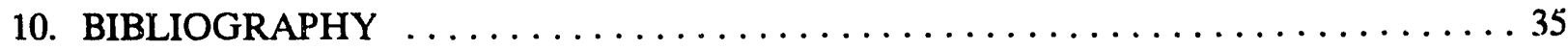

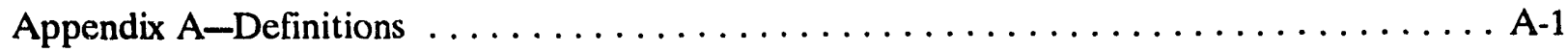

Appendix B-Federal, Threatened, Endangered, and Candidate Species and State

Species of Special Concern on the INEL $\ldots \ldots \ldots \ldots \ldots \ldots \ldots \ldots \ldots \ldots \ldots \ldots \ldots$

\section{FIGURES}

1. Map of INEL and immediate vicinity $\ldots \ldots \ldots \ldots \ldots \ldots \ldots \ldots \ldots \ldots \ldots \ldots \ldots$

2. A recommended site selection process $\ldots \ldots \ldots \ldots \ldots \ldots \ldots \ldots \ldots \ldots \ldots \ldots$

\section{TABLES}

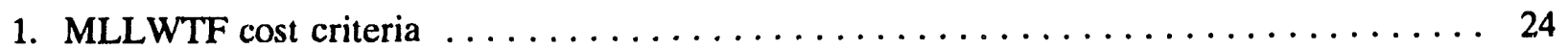

2. MLLWTF service and support siting criteria $\ldots \ldots \ldots \ldots \ldots \ldots \ldots \ldots \ldots \ldots \ldots$

3. MLLWTF environmental siting criteria $\ldots \ldots \ldots \ldots \ldots \ldots \ldots \ldots \ldots \ldots \ldots \ldots$

4. MLLWTF environmental siting guidelines $\ldots \ldots \ldots \ldots \ldots \ldots \ldots \ldots \ldots \ldots \ldots$

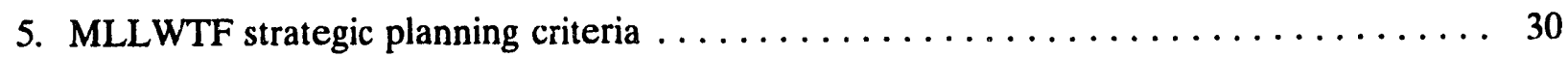




\section{ACRONYMS}

ACHP

AEA

ALMR

ANL-W

BLM

CERCLA

CFA

CFR

DOE

DOT

EG\&G Idaho

EPA

FWS

GDC

HSWA

ICRP

INEL

IWPF

LCC

MLLWTF

NEPA

NPR

NRC

NRF
Advisory Council on Historic Preservation

Atomic Energy Act

Advanced Liquid Metal Reactor

Argonne National Laboratories-West

Bureau of Land Management

Comprehensive Environmental Response, Compensation, and Liability Act

Central Facilities Area

Code of Federal Regulations

U.S. Department of Energy

U.S. Department of Transportation

EG\&G Idaho, Inc.

U.S. Environmental Protection Agency

U.S. Fish and Wildlife Service

General Design Criteria

Hazardous and Solid Waste Amendments

International Commission on Radiological Protection

Idaho National Engineering Laboratory

Idaho Waste Processing Facility

life-cycle cost

Mixed and Low-Level Waste Treatment Facility

National Environmental Policy Act

New Production Reactor

U.S. Nuclear Regulatory Commission

Naval Reactor Facility 
PCB

polychlorinated biphenyl

RCRA

Resource Conservation and Recovery Act

SHPO

State Historic Preservation Officer

TAN

Test Area North

TSCA

Toxic Substances Control Act

TSD

treatment, storage, and disposal 


\section{Preliminary Siting Criteria for the Proposed Mixed and Low-Level Waste Treatment Facility at the Idaho National Engineering Laboratory}

\section{INTRODUCTION}

The siting requirements for the proposed Mixed and Low-Level Waste Treatment Facility (MLLWTF) at the Idaho National Engineering Laboratory (INEL) are based on the laws and regulations that address the treatment, storage, and disposal (TSD) of hazardous, radioactive, and mixed wastes. The U.S. Environmental Protection Agency (EPA) regulations and U.S. Department of Energy (DOE) orders that specifically address facility siting are summarized in this report. Additionally, siting criteria have been developed from these requirements and a recommended approach for site selection is discussed. (Definitions of terms used in this report are provided in Appendix A.)

The MLLWTF is intended to treat, process and package waste contaminated with hazardous constituents and/or low-level beta-gamma radionuclides to meet disposal site waste acceptance criteria. Processing and treatment at the MLLWTF will be conducted in accordance with the standards required by DOE, EPA, and the State of Idaho. DOE's policy is to manage radioactive mixed waste according to the requirements of Subtitle $C$ of the Resource Conservation and Recovery Act (RCRA) and the Atomic Energy Act (AEA). RCRA applies to the extent that it is not inconsistent with the AEA.

The scope of the MLLWTF project at the INEL is to

- Protect human health and the environment

- Meet the waste acceptance criteria of the appropriate disposal facility

- Reduce the volume of waste

- $\quad$ Provide a stabilized waste form

- Treat mixed waste to satisfy EPA's treatment standards while complying with Federal, State, DOE, and EG\&G Idaho, Inc. (EG\&G Idaho) requirements. 


\subsection{Siting Assumptions}

Siting requirements are based on the assumption that the MLLWTF will be a DOE-owned facility located at the INEL. This report does not consider the siting requirements and impacts of other proposed facilities that could be co-located with the MLLWTF.

The following set of assumptions were used in developing the siting criteria for the MLLWTF project:

- The MLLWTF will be located at the INEL; thus, the region of interest is the $890 \mathrm{mi}^{2}$ encompassing the INEL.

- The MLLWTF will store polychlorinated biphenyls (PCBs) or PCB items with concentrations of $50 \mathrm{ppm}$ or greater, so the requirements of the Toxic Substances Control Act (TSCA) apply.

- The regulatory environment of the future will include the current requirements and the proposed requirements as drafted as of September 1992.

- The MLLWTF will comply with all currently applicable Federal, State, DOE, and EG\&G Idaho requirements.

- As a DOE site facility, U.S. Nuclear Regulatory Commission (NRC) siting requirements are not applicable to the MLLWTF.

- National Environmental Policy Act (NEPA) studies will be performed to aid decision makers in selecting the final site for the MLLWTF, as well as alternatives for offsite options.

- No transuranic waste will be treaied at this facility. 


\section{RECOMMENDED APPROACH FOR SITE SELECTION}

Three previous siting studies for proposed facilities at the INEL were reviewed to determine if their approaches could be applied to siting the MLLWTF: the New Production Reactor (NPR) (Spry 1989), the New Weapons Complex Reconfiguration Site, and the Advanced Liquid Metal Reactor (ALMR) (Sivill 1990a, Sivill 1990b). Figure 1 is a map of the INEL showing the locations selected for these proposed facilities. A fourth siting study, conducted for the proposed Idaho Waste Processing Facility (IWPF), is being conducted concurrently and cooperatively with the present MLLWTF study. The ALMR and NPR studies employed Kepner-Tregoe Decision Analysis for the site selection process. This process is used to clarify purpose, evaluate alternatives, assess risks, and make decisions.

Decision analysis provides a systematic framework that ensures all aspects of the decision are considered. The process uses the concepts of "musts" and "wants." "Musts" are those criteria considered to be minimum requirements for site acceptability. Proposed sites that do not meet each and every one of the "musis" requirements are to be eliminated from further consideration. "Wants" are those criteria considered to be desirable for site acceptability. Weighing factors, ranging in value from a low of 1 to a high of 10 , are assigned to each of the desirable criteria according to relative importance.

A recommended approach for the MLLWTF site selection is shown in Figure 2. The approach identifies the organization of two committees to complete the site selection process. An advisory committee is formed to make the determination of "musts" and "wants" and to assign weights to each of the "want" criteria based on their probability of occurrence and seriousness. After this process is completed, a field committee comprised of personnel with appropriate technical backgrounds uses the criteria iu select alternate locations. This is accomplished by first reviewing potential sites against the "musts" and making a first-cut reduction to exclude any sites that do not meet all of the mandatory requirements. The "wants" are then addressed. A system may be used where each site is scored on a scale of 1 to 10 relative to its ability tr satisfy each criterion. If a site can not meet a "want" criterion or does not have that specific attrib.te, the score will be zero in that area. Each criterion's score is then multiplied by that criterion's weighing factor, and the weighted scores for all criteria added to obtain a total weighted score for each site. Based on total weighted scores, each site is ranked to determine alternative locations for the facility.

At this point, the NEPA process is used to evaluate the potential environmental impacts of the site alternatives, as 'well as other programmatic alternatives. The NEPA process will be used to determine the final location of the MLLWTF at the INEL. As stated in DOE Order 6430.1A, "General Design Criteria," Section 0285-2.2.9, the final site approval for TSD facilities shall be obtained from the cognizant DOE operations office. Based on this, the DOE counterpart for the MLLWTF should become involved in the siting process during the early stages. 


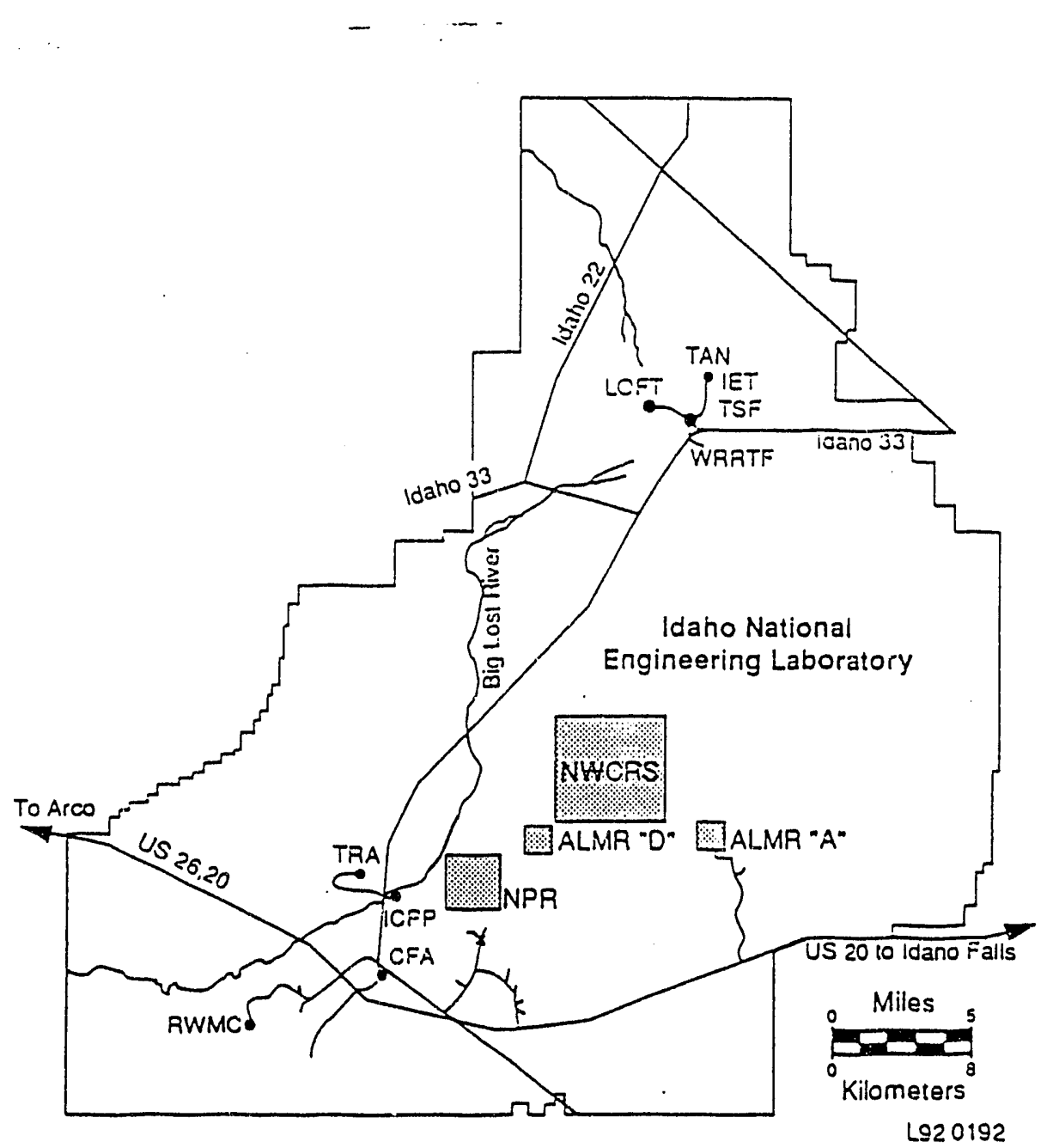

Figure 1. Map of INEL and immediate vicinity. 


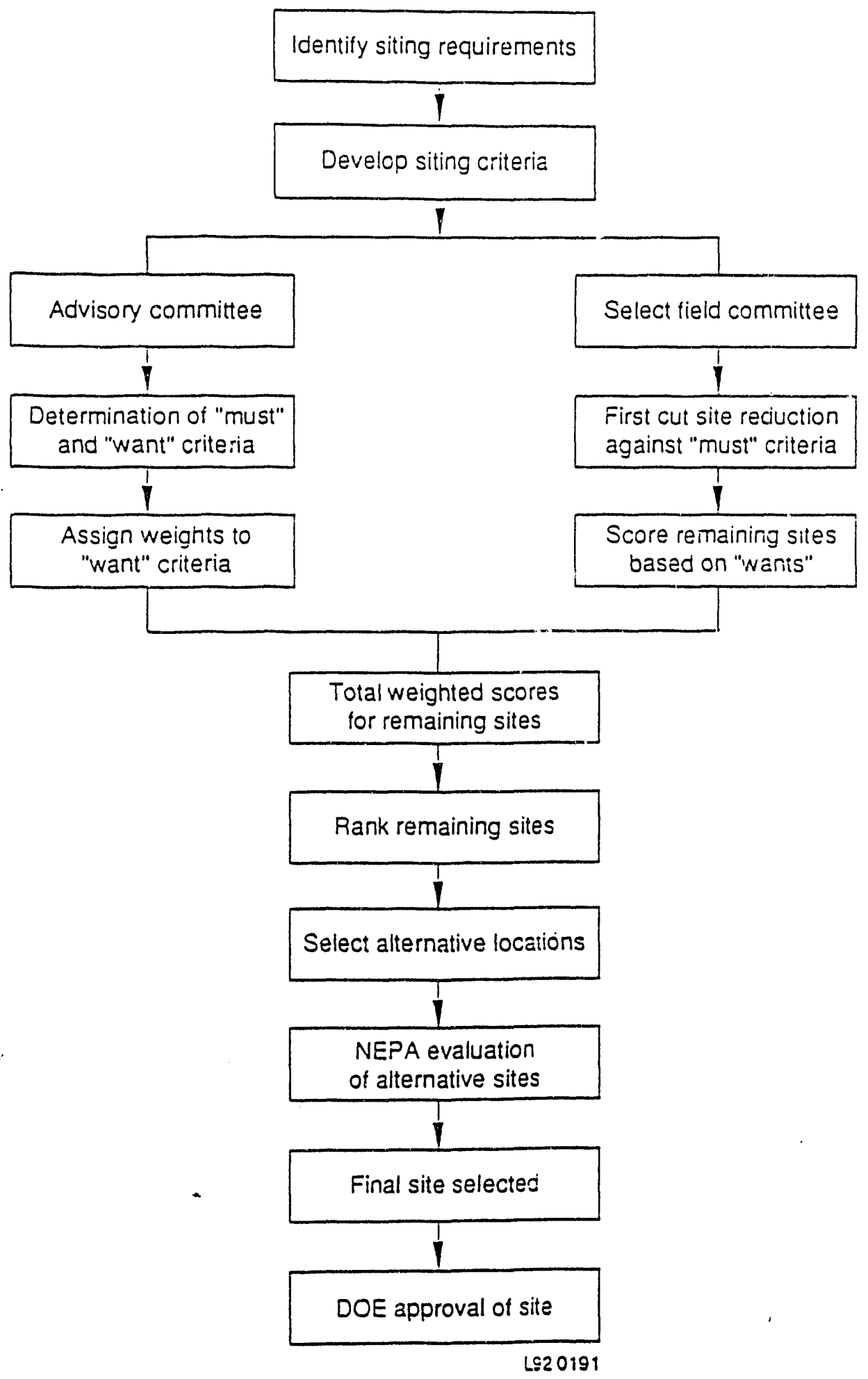

Figure 2. A recommended site selection process. 


\section{ENVIRONMENTAL REGULATIONS}

On December 18, 1978, the EPA proposed standards to control the location of TSD facilities in seismic zones, 100-year floodplains, coastal high hazard areas, 500-year floodplains, wetlands, critical habitats of endangered and threatened species, and recharge zones of sole-source aquifers, as well as specific standards to delimit the location of active portions of facilities with respect to the facilities' property lines. Public comment and additional research regarding the proposed standards were evaluated, and on January 12,1981, the EPA promulgated two of the eight candidate standards in their RCRA regulations: 'he 100-year floodplain and seismic zone restrictions. These minimum location standards for hazardous waste TSD facilities are contained in 40 Code of Federal Regulations (CFR) 264.18, and are discussed in Section 3.1 of this report.

Considerations affecting siting are also found in 40 CFR 270.14 (b) and (c), "Contents of Part B: General Requirements." These requirements reflect the standards promulgated in 40 CFR 264.18 and are necessary for the EPA to determine compliance with the Part 264 standards and are also discussed in Section 3.1 with the Part 264 regulations.

The EPA requires that other Federal laws that affect the location and permitting of TSD facilities be considered ( 40 CFR 270.3). When any of these laws is applicable, its procedures must be followed. These Federal laws are contained in Sections 3.2 through 3.13 of this report.

The AEA of 1954 (42 U.S.C. 2011 et seq.) authorizes DOE to establish standards to protect human health and minimize dangers to life and property. Through a scries of orders, DOE has established an extensive system for standards and requirements to ensure safe operations of its facilities. In accordance with the Energy Reorganization Act of 1974 (Public Law 93-438), only DOE facilities that accept commercial high-level waste are subject to licensing requirements by the NRC. Based on this requirement, siting of the MLLWTF is not subject to NRC regulations.

The 56 Federal Register 203 (p. 54057), October 21, 1991, contained the EPA's plans to "restrict the siting of hazardous waste treatment, storage, and disposal facilities in environmentally sensitive locations." The EPA designation of environmentally sensitive locations may have a great impact on the siting of the proposed MLLWTF. The EPA is considering proneness to catastrophic release, ecological sensitivity, and ability to characterize the site. Specific new concerns being considered are ground motion, unstable terrains, and areas over high resource aquifers. The Notice of Proposed Rulemaking for these location standards is scheduled for October 1992. The final rule is scheduled for April 1994. Since the INEL is located over the Snake River Plain Aquifer, which has been designated a sole source aquifer, these proposed standards could impact siting and design of the MLLWTF. This subject will have to be readdressed when the new standards are promulgated. 


\subsection{Resource Conservation and Recovery Act (42 U.S.C. 6921 et seq.)}

The purpose of 40 CFR 264, "Standards for Owners and Operators of Hazardous Treatment, Storage, and Disposal Facilities," is to establish minimum national standards that define the accep abie management of hazardous waste. Requirements of this part apply to owners or operators of all facilities that treat, store, or dispose of hazardous waste referred to in Part 268. These regulations address seisrnic considerations, floodplains, salt dome formations, salt bed formations, underground mines, and caves.

\subsubsection{Seismic Considerations}

Portions of new facilities where treatment, storage, or disposal of hazardous waste will be conducted must not be located within $61 \mathrm{~m}(200 \mathrm{ft})$ of a fault that has had displacement in Holocene time [i.e., during the last 10,000 years (See Appendix B)]. The intent of this standard is to ban new TSD facilities in locations on or near faults that are likely to experience displacement in the future.

In order to demonstrate the applicability of the seisnic standard, the owner or operator of a new facility must identify the political jurisdiction in which the p uposed facility is to be located (40 CFR 270.14). If the county is not listed in Appendix VI of Part 264, no further requirement is required to demonstrate compliance with 264.18. The Idaho counties listed in Appendix VI are Bannock, Bear Lake, Bingham, Bonneville, Caribou, Cassia, Clark, Franklin, Fremont, Jefferson, Madison, Oneida, Power, and Teton. The INEL lies within Bingham, Bonneville, Butte, Clark, and Jefferson counties.

If the facility is proposed to be located in an area listed in Appendix VI of Part 264, the owner or operator shall demonstrate compliance with the seismic standard. The major portion of the INEL lies in Butte County, which is not on the list. This means that if the facility were located in Butte County, it is assumed to be in compliance with the seismic requirements. If the proposed location of the facility is in a county listed in Appendix VI of Part 264, then this requirement will need to be addressed.

\subsubsection{Floodplains}

According to 40 CFR 264.10, "Applicability," the floodplain restrictions apply only to TSD facilities subject to regulation under Subparts I through $\mathrm{O}$ of this part. Subpart I addresses the use and management of containers and Subpart $O$ addresses incinerators; the MLLWTF will be subject to these subparts, so floodplain restrictions will apply. 
TSD facilities, subject to this regulation, are not permitted in the 100 -year floodplain unless one of three conditions are met:

- The facility is protected, by dikes or other equivalent measures, from washout during a 100-year flood

- Procedures are in effect that will cause the waste to be removed safeiy to a location where the wastes will not be vulnerable before flood waters can each the facility

- For existing surface impoundments, waste piles, land treatment units, landfills, and miscellaneous units, no adverse effects on human health or the environment will result if washout occurs.

\subsubsection{Salt Dome Formations, Salt Bed Formations, Underground Mines, and Caves}

According to 40 CFR 264.18(c), "the placement of any noncontainerized or bulk liquid hazardous waste in any salt dome formation, salt bed formation, underground mine, or cave is prohibited, except for the DOE-New Mexicc Waste Isolation Pilot Plant." There are caves lcuated at the INEL; however, because they will not be associated with the MLLWTF, this requirement is not applicable.

\subsection{Wild and Scenic Rivers Act (16 U.S.C. 1273 et seq.)}

Section 7 of the Wild and Scenic Rivers Act prohibits the regional administrator from assisting, by license or otherwise, the construction of any water resources project that would have a direct, adverse effect on the values for which a national wild and scenic river was established. Generally, the EPA interpretation of this obligation is to discourage the siting of TSD facilities in these riverine areas and adjoining lands to the extent that such facilities may impact these protected areas. The rivers located on the INEL are the Big Lost River, Little Lost River, and Birch Creek. None of these have been designated as a wild and scenic river, so this requirement is not applicable to the INEL.

\subsection{National Historic Preservation Act of 1966 (16 U.S.C. 470 et seq.)}

Section 106 of the National Historic Preservation Act and implementing regulations (36 CFR 800) require the regional administrator, before issuing a license, to adopt measures when feasible to mitigate potential adverse effects of the licensed activity and properties listed or eligible for listing in the National Register of Historical Places. 
The DOE, Advisory Council on Historic Preservation (ACHP), and the Idaho State Historic Preservation Officer (SHPO) require an archeological survey/consultative review of all projects that affect undisturbed areas. This requirement is applicable to the INEL because historic and prehistoric artifacts have been found here in the past. The report, Archeological Investigations on the Idaho National Engineering Laboratory, 1984-1985 (DOE 1991), can be used as a preliminary screening mechanism for sites, but an archeological survey will need to be performed on all candidate sites.

\subsection{Endangered Species Act of 1973 (16 U.S.C. 1531 et seq.)}

Section 7 of the Endangered Species Act and implementing regulations (50 CFR 17 and 402) require the regional administrator to ensure that any art autiorized by the EPA is not likely to jeopardize the continued existence of any endangered or threatened species or adversely affect its critical habitat. Generally, the EPA interpretation of this obligation is to prohibit the siting of TSD facilities within endangered or threatened species habitat. An ecological survey will need to be performed on candidate sites, along with consultation from the U.S. Fish and Wildlife Service (FWS), Idaho Fish and Game, and Bureau of Land Management (BLM) to determine if a critical habitat exists at a proposed location. Appendix B contains a list of Federal threatened, endangered, and candidate species and State species of concern that may occur on the INEL.

\subsection{Fish and Wildlife Coordination Act (16 U.S.C. 661 et seq.)}

The Fish and Wildlife Coordination Act requires that the regional administrator, before issuing a permit proposing or authorizing the impoundment, diversion, or other control or modification of any body of water, consult with the appropriate State agency exercising jurisdiction over wildlife resources to conserve those resources. This requirement is applicable if the MLLWTF project will impound, control, or modify the waters of a stream or other body of water that is greater than or equal to 10 acres in surface area.

\subsection{Coastal Zone Management Act (16 U.S.C. 1451 et seq.)}

The Coastal Zone Management Act requires that all Federal activities in coastal areas (see definitions in Appendix A) be consistent with approved State coastal zone management programs to the maximum extent possible. The INEL is not a coastal area, so this requirement does not apply.

\subsection{Wilderness Protection Act of 1964 (16 U.S.C. 1131 et seq.)}

The Wilderness Protection Act designates wilderness areas within public lands that include national parks, national wildlife refuges, national forests, and BLM lands. Designated wilderness areas cannot be used as sites for TSD facilities without congressional approval. The aforementioned land classifications are not located on the INEL, so this requirement does not apply. 


\subsection{Toxic Substances Control Act of 1976 (15 U.S.C. 2601 et seq.)}

The TSCA contained in 40 CFR Subchapter $R$ is applicable to the MLLWTF for the storage and treatment of PCBs specifically contained in 40 CFR Part 761, "Polychlorinated Biphenyls (PCBs) Manufacturing, Processing, Distribution in Commerce, and Use Prohibitions." Location standards apply to the storage for disposal of PCBs and PCB items at concentrations of $50 \mathrm{ppm}$ or greater. These standards are contained in 40 CFR 761.65 (b) (1) (v), "Storage for Disposal," and prohibit locations at sites "below the 100 -year flood water elevation."

\subsection{Clean Air Act of 1970 (42 U.S.C 7401 et seq.)}

The 1977 amendments to this act used EPA's three-class zoning system (i.e., Class I, II, and III areas) that provide for certain aliowable increments of additional pollution in each. Section 162 defines all national parks and wilderness areas above a certain size $(5,000$ to 6,000$)$ acres, depending on the type of park) Class I areas that cannot be redesignated. Section 169A designed a program for "the prevention of any future, and the remedying of any existing, impairment of visibility" in Class I areas from man-made air pollution. In the vicinity of the INEL, Craters of the Moon National Monumen:, Yellowstone National Park, and Grand Teton National Park are Class I air quality areas. Development that impairs the visibility of these areas will not be eligible for an air quality permit from the State of Idaho. In siting the MLLWTF, a determination of potential emissions from the facility must be made and used to site the facility such that there will be no visibility impairment to any Class I area.

\subsection{Wetlands (Executive Order 11990)}

Executive Order 11990 entitled, "Protection of Wetlands," directs Federal agencies to avoid undertaking or providing assistance for new construction of projects located on Federally-owned wetlands (see definitions in Appendix A) unless there is no practical alternative. In cases where there is no alternative site, all measures must be taken to minimize harm to the wetland. DOE has issued regulations in 10 CFR 1022 that establish procedures for compliance with this order. Wetlands may occur at the INEL during high water stages of the Big Lost River. These areas will need to be identified and eliminated from the siting investigation.

\subsection{Floodplains (Executive Order 11988)}

Executive Order 11988, entitled "Floodplain Management," requires governmental agencies to avoid, to the extent possible, impacts associated with the occupancy and modification of floodplains. This order is also implemented in 10 CFR 1022. Because floodplains are more strictly regulated under TSCA and RCRA, this order will have no additional impact on siting the MLLWTF on the INEL. 


\subsection{National Environmental Policy Act (42 U.S.C. 4321 et seq.)}

All potential projects involving any Federal agency must undergo a review pursuant to NEPA to identify and evaluate potential environmental impacts. NEPA constitutes a national policy to protect the environment and to promote a better understanding of the ecological systems and natural resources that are important to the nation. The Council on Environmental Quality regulations implementing NEPA contain "action-forcing" provisions to ensure that Federal agencies consider environmental information before making decisions on proposed actions. The NEPA process includes decision points at which the significance of environmental effects are considered, project alternatives are identified, and appropriate mitigation measures are identified and adopted.

DOE Order 5440.1D, "National Environmental Policy Act Compliance Program," describes the roles of various DOE offices in implementing NEPA. It also states that DOE's policy is to comply fully with the letter and spirit of NEPA. Based on the requirements in 10 CFR 1021, "National Environmental Policy Act Implementing Procedures," the siting of the MLLWTF will probably involve the preparation of an environmental impact statement. Environmental concerns should be evaluated in the early planning stages, and documentation should begin as soon as possible. The NEPA process should be used to evaluate alternative sites and aid decision makers in selecting the final site for the MLLWTF.

\subsection{National Emission Standards for Hazardous Air Pollutants (40 CFR 61 Subpart H)}

Part 61.07 of 40 CFR, "Application for Approval of Construction or Modification," requires that an application for approval of construction of any new source be submitted to the EPA. The application must include the location or proposed location and full facility description, as well as calculations of emission estimates, in sufficient detail to permit assessment of calculation validity.

Some primary requirements are contained in Subpart H, "National Emissions Standards for Emissions of Radionuclides Other than Radon from Department of Energy Facilities." Part 61.90 designates that this subpart applies to operations at any DOE facility that emits any radionuclide other than radon-222 and radon-220 into the air. Part 61.92 states that emissions of radionuclides to the air shall not exceed those amounts that would cause any member of the public to receive in any year an effective dose equivalent of $10 \mathrm{mrem}$. Methods to determine compliance with this standard and monitoring and sampling requirements are specified in Part 61.93. 


\section{DOE Order 6430.1A, "General Design Criteria," Environmental Siting Requirements}

The purpose of DOE Order 6430.1A, "General Design Criteria," is to "provide general design criteria (GDC) for use in the acquisition of the Department's facilities and to establish responsibilities and authorities for the development and maintenance of these criteria." It is DOE policy that the planning, design, and construction of DOE facilities be performed in a manner that will satisfy all applicable executive orders, Federal laws, and regulations. The majority of this order is based on considerations to be observed during siting, and are not actual requirements. Division 2, "Site and Civil Engineering," contains the majority of the requirements applicable to the siting of a new facility. The environmental requirements from this division are discussed in this section of the report, while the service and support requirements from this division and those from Division 1, "Generai Requirements," are discussed in Section 6 of this report.

\subsection{Section 0200, "Site Development"}

\subsubsection{Section 0200-1, "Facility Siting"}

Section 0200-1 states that a site development plan shall be used to locate new facilities on existing or new sites to ensure effective site utilization and to preclude future conflicts between existing and new facilities. The following conditions and requirements shall be considered during site selection for a new facility:

- Programmatic and operating efficiency

- Natural opographic and geologic conditions

- Existing cultural, historic, and archaeological resources

- Endemic plant and animal species

- Existence of known RCRA and/or Comprehensive Environmental Response, Compensation, and Liability Act (CERCLA) sites

- Special siting requirements for facilities containing, using, or processing hazardous materials

- Health, safety, and environmental protection requirements

- Indoor air quality impacts 
- Hazardous operations and consequences of potential accidents in adjacent facilities

- Natural hazards

- Physical protection requirements

- $\quad$ Security and safeguard requirements

- Adequacy of existing or planned support and service facilities, including utilities, roads, and parking areas

- Inter-relationships between facilities and aesthetic compatibility

- Energy conservation requirements

- Impact of site selection.

This section states that the above conditions should be considered during site selection, but does not specifically prohibit any locations.

4.1.1.1 Radiological Considerations. For those facilities in which radioactive materials are processed, used, or stored, the acceptability of the site shall be evaluated in terms of potential radiological consequences. The accidents to be considered are those attributable to both operational events and natural phenomena.

The following siting guidelines apply to offsite individuals receiving maximum dose from exposure to internally-deposited radioactive materials and/or radiation from external sources. Guidelines are based on a 50-year committed dose equivalent. The maximum calculated dose shall not exceed $25 \mathrm{rem}$ to the whole body, $300 \mathrm{rem}$ to the thyroid, $300 \mathrm{rem}$ to the bone surface, $75 \mathrm{rem}$ to the lung, or 150 rem to any other organ. If multiple organs receive doses from the same exposure, the effective dose equivalent from all sources shall not exceed 25 rem when calculated using the weighting factors defined by the International Commission on Radiological Protection (ICRP), Report No. 26. These guidelines will be used in siting the MLLWTF.

\subsubsection{Section 0200-2, "Building Location"}

This section states that new buildings and building additions shall be located in accordance with a site development plan. Conditions are listed for siting consideration, including those listed in Section 4.1 of this report and also architectural and functional compatibility requirements. 


\subsubsection{Section 0200-99, "Special Facilities"}

This section requires site evaluation and studies necessary to provide the technical basis for location, with appropriate consideration given to the immediate and long-term consequences of releases of radioactive or other hazardous materials to the environment. The potential hazards from other onsite facilities and offsite sources of hazards that could affect the safe operation of the facility shall be considered. Proximity to utilities, the fire department, and other services shall be considered. In addition, meteorological, hydrological, and seismological studies shall be performed in accordance with the requirements in this section.

\subsection{Section 0285, "Solid Waste Systems"}

Site selection is the most critical step in establishing TSD facilities for hazardous, nonhazardous, and low-level radioactive waste. The following conditions and requirements shall be considered during the selection of solid waste TSD sites:

- Existing groundwater and surface water conditions

- Soil, geologic, and topographic features

- Solid waste types and quantities

- Social, geographic, and economic factors

- $\quad$ Aesthetic and environmental impacts.

This section states that the above conditions be considered during site selection, but does not specifically prohibit any locations.

\subsubsection{Section 0285-2.2.2, "Environmentally Sensitive Areas"}

The following environmentally sensitive areas shall be avoided or receive lowest siting priority for treating, storing, and disposing of hazardous, nonhazardous, and radioactive solid waste:

- Wetlands

- Areas within the 500-year floodplain

- Permafrost areas

- Critical habitats of endangered species 
- $\quad$ Recharge zones of sole-source aquifers

- Watersheds for domestic water supply.

This section states that the above locales be avoided or given lowest priority. Since all but the 500year floodplain are already restricted by other laws or do not apply to the INEL (i.e., permafrost areas), this will have little impact on siting of the MLLWTF. The 500-year floodplain will neeci to be considered when siting the proposed MLLWTF.

\subsubsection{Section 0285-2.2.3, "Fault Zones and Karst Terrain"}

When potential sites are screened for location of new solid waste TSD facilities, seismic zones and karst (limestone formation) terrain shall be avoided unless site-specific evaluations demonstrate minimum potential for contamination of surface water, groundwater, and other environmental resources. The INEL has no karst terrain, but seismic zones will need to be investigated further when siting the proposed MLLWTF.

\subsubsection{Section 0285-2.2.4, "Cost Effectiveness"}

Life-cycle cost (LCC) analysis shall be performed during site selection for TSD facilities. LCC analysis shall include site reclamation costs.

\subsubsection{Section 0285-2.2.5, "Sites Traversed by Utilities"}

Sites traversed by buried pipe utilities shall not be used for TSD facilities unless the relocation or protection of these utilities is economically feasible. Buried pipe utility trenches can serve as a pathway for the migration of contaminants. This restriction does apply to the proposed MLLWTF.

\subsubsection{Section 0285-2.2.6, "Characteristics and Availability of Soil Cover"}

The characteristics and availability of onsite soil cover shall be considered with respect to site operation and performance requirements.

\subsubsection{Section 0285-2.2.7, "Site Access"}

Sites shall be accessible to service and refuse collection vehicles by all-weather road extensions from primary road systems.

\subsubsection{Section 0285-2.2.8, "Effects on Other Facilities"}

Sites that would adversely affect operation of other facilities shall be avoided. The following effects shall be considered: 
- Vehicular traffic

- $\quad$ Noise

- Litter

- $\quad$ Bird strike

- Vectors (i.e., insects or rodents)

- Other nuisance conditions.

This restriction does apply to the proposed MLLWTF.

\subsubsection{Section 0285-2.2.9, "Site Approval"}

Final site approval for TSD facilities for hazardous, nonhazardous, and low-level radioactive wastes shall be obtained from the cognizant DOE Field Office. 


\section{IDAHO LAWS AND REGULATIONS}

All Idaho documentation containing siting requirements refer to Federal or DOE legislation already discussed in previous sections and is included here as reference material:

Idaho Air Pollution Control Regulations

IDAPA 16.01. 1000 , "Rules and Regulations for the Control of Air Follution in Idaho"

IDAPA 16.01.01012, "Procedures and Requirements fo: " ermits to Construct and Operate"

IDAPA 16.01.01101, "Air Quality Standards and Area Classification"

IDAPA 16.01.01251, et seq., "Rules for Control of Fugitive Dust"

IDAPA 16.01.01951, et seq., "Regulation of Standards of Performance for New Stationary Sources"

Idaho Water Pollution Control Law

IDAPA 16.01.08000, "Idaho Drinking Water Regulations"

IDAPA 16.01.08700, et seq., "Construction Requirements for New Water Systems or Modifications to Existing Systems"

Idaho Hazardous Waste Management Regulations

IDAPA 16.01.05000, "Rules, Regulations and Standards for Hazardous Waste"

IDAPA 16.01.05008-05356, "Standards for Owners and Operators of Hazardous Waste Treatment, Storage, and Disposal Facilities" 


\section{SERVICE AND SUPPORT REQUIREMENTS}

The MLLWTF service and support siting criteria were developed from the requirements contained in DOE orders, CFRs, commercial standards, and executive orders. The following EG\&G Idaho departments also were contacted to obtain additional information and verify requirements: Security; Facilities and Maintenance; Environment, Safety, and Quality; Fire Protection; Occupational Medical; and Waste Management Operations. Service and support siting requirements are presented here in the following categories:

- Security

- Fire protection

- Occupational medical

- Commercial power

- Water

- Roads

- Traffic control

- Sanitary water treatment.

Regulations and requirements for these service and support categories are presented in the following subsections.

\subsection{Security}

"General Facility Security," 40 CFR 264, addresses access control for a hazardous waste facility. This document states that the owner or operator of a hazardous waste facility must prevent the unknowing entry and minimize the possibility for the unauthorized entry of persons or livestock onto the active portion of the facility. The MLLWTF is a RCRA TSD facility; therefore, this access control requirement applies. The cost of providing security for the MLLWTF may be minimized by siting within or near an existing facility.

\subsection{Fire Protection}

DOE Order $6430.1 \mathrm{~A}$ states that existing fire protection facilities shall be considered in the siting process. Fire protection is a support function with fire stations at Central Facilities Area (CFA), Test 
Area North (TAN), and Argonne National Laboratories-West (ANL-W). Best management practice suggests that the MLLWTF be sited as close to one of these facilities as possible to minimize response time to a fire.

\subsection{Occupational Medical}

Occupational medical serves a support function with facilities (i.e., infirmaries) located at CFA, Idaho Chemical Processing Plant, Test Reactor Area, TAN, Naval Reactor Facility (NRF), and ANLW. Best management practice suggests that the MLLWTF be sited as close to one of these facilities as possible to minimize response time to a medical emergency. Since DOE Order 6430.1A states existing occupational medical facilities shall be considered, minimizing response time to a medical emergency shall be considered a "want" and weighted accordingly through the site evaluation process.

\subsection{Commercial Power}

Commercial power required for the MLLWTF can be delivered either by transmission lines that can be run either above or below grade. Due to the widespread occurrence of basalt at or near the ground surface at the INEL and the difficulty and cost of excavating in lava rock, the assumption is made that all power lines shall be placed above grade.

Since the total demand for power is an unknown quantity at this time, a "want" siting criteria is to minimize the length of new power lines to the MLLWTF from existing power distribution lines.

\subsection{Potable Water}

DOE Order 6430.1A, Section 266.2, states "domestic water conveyed within distribution systems that serve DOE facilities shall comply with the applicable Safe Drinking Water Act (SDWA), 40 CFR 141 requirements and with all other State, regional, and local requirements." The following requirements for potable water are provided in these documents:

- 40 CFR 141, Section 5, "Siting Requirements." Before a person may enter a financial commitment for or initiate construction of a new public water system or increase the capacity of an existing public water system, he shall notify the state and, to the extent practicable, avoid locating part of or all the new or expanded facility at a site that is subject to a significant risk from earthquakes, floods, fires, or other disasters that could cause a breakdown of the public water system or a portion thereof; or is within the floodplain of a 100-year flood or is lower than any recorded high tide (not applicable for intake structures) 
- 40 CFR 264, Subpart C, Section 32, "Required Equipment." This section provides requirements for such items as pumps, supply lines, valves, and any other equipment needed to supply water to a facility.

The quality of drinking water supplied to the MLLWTF must meet State and Federal drinking water standards. For this reason, groundwater should not be drawn from locations at which known contaminated groundwater plumes exist or are anticipated to exist based on available groundwater monitoring data and modeling studies. Locations $a^{t}$ the INEL where contaminated groundwater plumes exist or are anticipated to exist are summarized in Orr and Cecil (1991) although other sources of information also should be investigated.

DOE Order 6430.1A states that existing water supply facilities capable of providing adequate potable water to the MLLWTF should be identified and considered in siting the facility. This will help reduce the capital cost of the MLLWTF.

\subsection{Roads}

Access to the MLLWTF facility is addressed in DOE Order 6430.1A, Section 0250-3, which states, "geometric design of a!l roads, streets, access drives, and parking areas shall comply with AASHTO [American Association of State Highway ar d Transportation Officials] GDHS-84," which provides design requirements for the geometric construction of paved surfaces.

All roads constructed to support the MLLWTF must meet the above requirements; existing paved roads are assumed to meet these requirements. In keeping with DOE Order 6430.1A, which states "the adequacy of existing or planned support and service facilities including utilities, roads, and parking areas shall be considered," the adequacy of existing or planned roads should be considered in siting the MLLWTF.

Regulations that address the transportation of hazardous and mixed waste across public accesses (e.g., U.S. Highways 26. 20, 33, and 22) must be considered in siting the MLLWTF. These regulations are contained in the U.S. Department of Transportation (DOT) requirements provided in 49 CFK Subchapter C, "Hazardous Materials Regulations," which states that in order to use a public access to transport hazardous or mixed waste, a licensed cask such as a transuranic pack or control access to that road (close the road and prepare a transport plan) must be employed. DOE ID 5480.3 states requirements for transportation of hazardous materials beyond the security boundary of DOE-ID facilities, even when public highways are not involved, and recommends that DOT regulations be complied with. However, the order does not apply to on-site movements of hazardous materials within a specific INEL security boundary. Best management practice to reduce risk of exposing the public to a hazardous or mixed waste spill would be to minimize the transportation of waste. 


\subsection{Traffic Control}

Traffic control is addressed in DOE Order 6430.1A, Section 0250-6, which states "signs, pavement markings, and channelization shall comply with ANSI D6.1." Since traffic control facilities are support facilities, existing traffic control facilities must be considered in siting the MLLWTF in keeping with this order.

\subsection{Sanitary Water Treatment}

Wastewater services are addressed in DOE Order 6430.1A, Section 0267-1, which states, "complete chemical analyses of potential water source shall be acquired prior to selection of industrial water treatment processes." Section 0270-1, "Sanitary Wastewater Collection System," states, "wastewater collection system layouts shall be as simple and direct as possible."

This section provides the following specific requirements for wastewater service, which will be considered essential for siting the MLLWTF:

- Velocities in gravity sewers and force mains shall not exceed $10 \mathrm{ft} / \mathrm{s}$

- Gravity sewers shall be designed for a minimum velocity of $2 \mathrm{ft} / \mathrm{s}$

- Force mains shall be designed for a minimum velocity of $3.5 \mathrm{ft} / \mathrm{s}$.

The MLLWTF sewer service must meet all of the above requirements.

Sewer service facilities are support facilities; therefore, existing sewer service facilities must be considered in keeping with DOE Order 6430.1A, which states, "during site selection for new facilities, adequacy of existing or planned support and service facilities including utilities, roads, and parking areas shall be considered." Use of existing sewer service facilities would lower the capital cost of the MLLWTF; therefore, the MLLWTF should maximize the use of existing excess sewer service capacity.

\subsection{General Service and Support}

The following are also relevant to siting the MLLWTF:

- Maximize the distance from public highways.

- Minimize the commuting distance from Idaho Falls, Pocatello, and Blackfoot.

- Minimize the length of new roads. 
- Minimize the cost of excavation by avoiding excavation in basalt rock. This requirement is an effort to minimize new construction cost.

- Maximize distance from Site boundaries.

- Use of existing service and support facilities to support the MLLWTF should not negatively impact existing facilities (i.e., increase fire risk to neighboring facility, contamination release down wind of the MLLWTF, pumping an existing facility's production well dry, overloading existing traffic patterns). Potential negative impacts on planned facilities should be considered on a case-by-case basis. 


\section{SITE SELECTION CRITERIA}

The site selection criteria were developed to identify the requirements of the following siting categories:

- Cost (fixed, maintenance, operational, other)

- Service and support

- Environmental

- Archeological

- Geological

- Health and safety

- Others, as required.

\subsection{Cost Criteria}

Criteria were developed to minimize costs associated with utilities, roads, construction, and travel (see Table 1). These costs will be driven by whether or not the site has these existing capabilities or they have to be developed. The focus of the criteria based on cost is on minimization of costs associated with each candidate site. Additionally, DOE Order 6430.1A, Section 0285-2.2.4, requires that life-cycle cost analysis, including site reclamation costs, be performed for site selection of TSD facilities.

\subsection{Service and Support Siting Criteria}

Service and support siting criteria and guidelines identified in Section 6 of this report are summarized in Table 2.

\subsection{Environmental Criteria}

Environmental criteria were developed based on environmental requirements identified in Section 3 and 4. The most restrictive environmental criterion stems from TSCA and prohibits locations in the 100-year floodplain if the MLLWTF stores PCBs (see Section 3.8). RCRA as implemented in 40 CFR 264.18 restricts locations of TSD facilities based on seismic and floodplain considerations. Additional environmental criteria were developed to include those areas that would have an environmental impact as a result of siting. Table 3 identifies the criteria developed from 
Table 1. MLLWTF cost criteria.

\begin{tabular}{|c|c|c|}
\hline Criteria area & Regulations/requirements & Criteria \\
\hline $\begin{array}{l}\text { Proximity to related } \\
\text { facilities }\end{array}$ & Best management practice & $\begin{array}{l}\text { Consider location near the proposed } \\
\text { MLLWDF to minimize } \\
\text { transportation, utility, and } \\
\text { administration costs. }\end{array}$ \\
\hline $\begin{array}{l}\text { Utilities (buried } \\
\text { pipe) }\end{array}$ & $\begin{array}{l}\text { "General Design Criteria," } \\
\text { DOE } 6430.1 \mathrm{~A}\end{array}$ & $\begin{array}{l}\text { Sites traversed by buried pipe utilities } \\
\text { shall not be used for TSD facilities } \\
\text { unless the relocation or protection of } \\
\text { these utilities is economically feasible } \\
\text { (Section 4.2.4). }\end{array}$ \\
\hline Sewer services & $\begin{array}{l}\text { "General Design Criteria," } \\
\text { DOE 6430.1.A; best } \\
\text { management practice }\end{array}$ & $\begin{array}{l}\text { Maximize the use of existing sewer } \\
\text { service facilities (Section 6.8). }\end{array}$ \\
\hline Commercial power & $\begin{array}{l}\text { "General Design Criteria," } \\
\text { DOE } 6430.1 \mathrm{~A} \text {; best } \\
\text { management practice }\end{array}$ & $\begin{array}{l}\text { Minimize the length of new power } \\
\text { lines to the MLLWTF from existing } \\
\text { power distribution lines (Section 6.4). }\end{array}$ \\
\hline Potable water & $\begin{array}{l}\text { "General Design Criteria," } \\
\text { DOE } 6430.1 \mathrm{~A} \text {; best } \\
\text { management practice }\end{array}$ & $\begin{array}{l}\text { Minimize cost of supplying potable } \\
\text { water to the MLLWTF. } \\
\text { Groundwater must not be drawn } \\
\text { from locations at which known } \\
\text { contaminated groundwater plumes } \\
\text { exist, are known to exist, or are } \\
\text { anticipated to exist (Section } 6.5 \text { ). }\end{array}$ \\
\hline Roäts & $\begin{array}{l}\text { "Hazardous Materials } \\
\text { Regulations," DOT } \\
\text { requirements in } 49 \mathrm{CFR} \\
\text { Subchapter C }\end{array}$ & $\begin{array}{l}\text { Minimize use of roads for } \\
\text { transporting hazardous waste to the } \\
\text { MLLWTF (Section 6.6). }\end{array}$ \\
\hline
\end{tabular}


Table 2. MLLWTF service and support siting criteria.

\begin{tabular}{|c|c|c|}
\hline Criteria area & Regulations/requirements & Criteria \\
\hline Security & $\begin{array}{l}\text { "General Design Criteria," } \\
\text { DOE } 6430.1 \mathrm{~A}\end{array}$ & $\begin{array}{l}\text { If possible, the MLLWTF should be } \\
\text { sited within the fence line of an } \\
\text { existing secure facility or located } \\
\text { close enough to the fenceline of an } \\
\text { existing secure facility to permit the } \\
\text { extension of the existing fenceline to } \\
\text { enclose the MLLWTF (Section 6.1). }\end{array}$ \\
\hline Fire protection & $\begin{array}{l}\text { "General Design Criteria," } \\
\text { DOE } 6430.1 \mathrm{~A} \text {; best } \\
\text { management practice }\end{array}$ & $\begin{array}{l}\text { Minimize the response time from an } \\
\text { existing fire fighting facility to the } \\
\text { MLLWTF (Section 6.2). }\end{array}$ \\
\hline Occupational medical & $\begin{array}{l}\text { "General Design Criteria," } \\
\text { DOE } 6430.1 \mathrm{~A} \text {; best } \\
\text { management practice }\end{array}$ & $\begin{array}{l}\text { Minimize the response time from the } \\
\text { MLLWTF to the existing medical } \\
\text { facilities (Section 6.3). }\end{array}$ \\
\hline
\end{tabular}

these regulations and requirements. Siting guidelines, less defined and binding than the criteria, are presented in Table 4.

\subsection{Archeological Criteria}

The National Historic Preservation Act, as implemented in 36 CFR 800, requires the mitigation of potential adverse effects on archeological or historical sites. This was developed into a siting criterion (see Tables 3 and 4).

\subsection{Geological Criteria}

In addition to the floodplain and seismic criteria stated in Section 7.3, other geological criteria were developed to address seismic and volcanic zones (see Tables 3 and 4). There are no clear definitions of these zones except by the NRC, whose regulations do not govern the MLLWTF but in this case may be used as a best management practice.

\subsection{Health and Safety Criteria}

Two criteria were developed based on the radiological requirements in 40 CFR 61 and DOE Order 6430.1A (sce Table 3). The criterion was designed for low risk of public exposure to radiation. Additional health and safety criteria were developed to address distance from site boundaries, and interactions with existing facilities, (see Tables 3, 4, and 5). 
Table 3. MLLWTF environmental siting criteria.

\begin{tabular}{|c|c|c|}
\hline Criteria area & Regulations/requirements & Criteria \\
\hline Air quality & $\begin{array}{l}\text { Clean Air Act of } 1970 \text { (42 } \\
\text { U.S.C. } 7401 \text { et seq.) }\end{array}$ & $\begin{array}{l}\text { The MLLWTF cannot be located in } \\
\text { a site such that air emissions from } \\
\text { the facility will visibly impair any } \\
\text { Class I area (Section } 3.9 \text { ). }\end{array}$ \\
\hline $\begin{array}{l}\text { Archeological/ } \\
\text { historical }\end{array}$ & $\begin{array}{l}\text { National Historic Preservation } \\
\text { Act of } 1966 \text { (16 U.S.C. } 470 \mathrm{et} \\
\text { seq.) }\end{array}$ & $\begin{array}{l}\text { The MLLWTF cannot have any } \\
\text { direct adverse impacts on sites listed } \\
\text { or eligible for listing on the National } \\
\text { Register of Historic places } \\
\text { (Section 3.3). }\end{array}$ \\
\hline $\begin{array}{l}\text { CERCLA or RCRA } \\
\text { sites }\end{array}$ & $\begin{array}{l}\text { "General Design Criteria," } \\
\text { DOE Order } 6430.1 \mathrm{~A}\end{array}$ & $\begin{array}{l}\text { Locations of known RCRA and } \\
\text { CERCLA sites shall be avoided in } \\
\text { locating the MLLWTF (Section } \\
\text { 4.1.1). }\end{array}$ \\
\hline $\begin{array}{l}\text { Endangered or } \\
\text { threatened species }\end{array}$ & $\begin{array}{l}\text { Endangered Species Act of } \\
1973 \text { (16 U.S.C. } 1531 \text { et seq.) }\end{array}$ & $\begin{array}{l}\text { The MLLWTF cannot be located } \\
\text { within an endangered or threatened } \\
\text { species critical habitat (Section } 3.4 \text { ). }\end{array}$ \\
\hline \multirow[t]{2}{*}{$\begin{array}{l}\text { Geological features- } \\
\text { seismic zones and } \\
\text { karst terrain }\end{array}$} & $\begin{array}{l}\text { "Standards for Owners and } \\
\text { Operators of Hazardous Waste } \\
\text { Treatment, Storage, and } \\
\text { Disposal Facilities," } 40 \text { CFR } \\
264.18\end{array}$ & $\begin{array}{l}\text { The MLLWTF shall not be located } \\
\text { within } 61 \mathrm{~m}(200 \mathrm{ft}) \text { of a fault that } \\
\text { has had displacement in Holocene } \\
\text { time (i.e., during the last } 10,000 \\
\text { years) (Section 3.1.1). }\end{array}$ \\
\hline & $\begin{array}{l}\text { "General Design Criteria," } \\
\text { DOE Order } 6430.1 A\end{array}$ & $\begin{array}{l}\text { Fault zones and karst terrain shall be } \\
\text { avoided or receive the lowest siting } \\
\text { priority (Section 4.2.2). }\end{array}$ \\
\hline Radiological & $\begin{array}{l}\text { "National Emission Standards } \\
\text { for Emissions of Radionuclides } \\
\text { other than Radon from } \\
\text { Department of Energy } \\
\text { Facilities," } 40 \text { CFR } 61 \\
\text { Subpart H }\end{array}$ & $\begin{array}{l}\text { The MLLWTF must be sited such } \\
\text { that emissions of radionuclides to the } \\
\text { air shall not exceed those amounts } \\
\text { that would cause any member of the } \\
\text { public to receive an effective dose } \\
\text { equivalent of } 10 \mathrm{mrem} / \mathrm{yr} \\
\text { (Section } 3.13 \text { ). }\end{array}$ \\
\hline
\end{tabular}


Table 3. (continued).

\begin{tabular}{lll}
\hline Criteria area & Regulations/requirements & \multicolumn{1}{c}{ Criteria } \\
\hline & "General Design Criteria," & The MLLWTF must be sited such \\
DOE Order 6430.1A & $\begin{array}{l}\text { that potential accidents attributable } \\
\text { to both operational and natural } \\
\text { phenomena do not result in doses to } \\
\end{array}$ & $\begin{array}{l}\text { offsite individuals that exceed levels } \\
\text { given in Section 4.1.1.1. }\end{array}$
\end{tabular}

Water, surface-flood 40 CFR 761, "Polychlorinated plains

Biphenyls (PCBs)
Manufacturing, Processing, Distribution in Commerce, and Use Prohibitions"

40 CFR 264.18, "Standards for Owners and Operators of Hazardous Waste Treatment, Storage, and Disposal Facilities"

"General Design Criteria," DOE Order 6430.1A; Section 0285; Subpart 2
The MLLWTF cannot be located at a site below the 100 -year flood water elevation if the facility contains PCBs or $\mathrm{PCB}$ items with concentrations of $50 \mathrm{ppm}$ or greater (Section 3.8).

If the MLLWTF does not store PCBs or PCB items but stores RCRA hazardous or mixed waste, it cannot be located in the 100-year flood plain unless it meets one of three conditions: (a) the facility is protected, via dikes or other equivalent measures, from washout during a 100-year flood, (b) all hazardous materials can be moved to safe ground prior to flooding, and (c) it can be demonstrated that no adverse effects to human health and the environment will occur should flood waters reach the waste (Section 3.1.2).

500-year floodplains shall be avoided or receive the lowest siting priority for TSD of hazardous, nonhazardous, and radioactive solid waste

(Section 4.2.1). 
Table 3. (continued).

\begin{tabular}{|c|c|c|}
\hline Criteria area & Regulations/requirements & Criteria \\
\hline $\begin{array}{l}\text { Water, surface- } \\
\text { watersheds for } \\
\text { domestic water } \\
\text { supply }\end{array}$ & $\begin{array}{l}\text { "General Design Criteria," } \\
\text { DOE Order } 6430.1 \mathrm{~A}\end{array}$ & $\begin{array}{l}\text { Watersheds for domestic water supply } \\
\text { shall be avoided or receive the lowest } \\
\text { siting priority for TSD of hazardous, } \\
\text { nonhazardous, and radioactive solid } \\
\text { waste (Section } 4.2 .1 \text { ). }\end{array}$ \\
\hline Water, groundwater & $\begin{array}{l}\text { "General Design Criteria," } \\
\text { DOE Order } 6430.1 \mathrm{~A}\end{array}$ & $\begin{array}{l}\text { Recharge zones for sole source } \\
\text { aquifers shall be avoided or receive } \\
\text { the lowest priority rating for TSD of } \\
\text { hazardous, nonhazardous, and } \\
\text { radioactive solid waste } \\
\text { (Section } 4.2 .1 \text { ). }\end{array}$ \\
\hline \multirow[t]{2}{*}{ Wetlands } & $\begin{array}{l}\text { "Protection of Wetlands," } \\
\text { Executive Order } 11990\end{array}$ & $\begin{array}{l}\text { Federal agencies shall avoid } \\
\text { undertaking new construction } \\
\text { projects located on Federally-owned } \\
\text { wetlands (Section } 3.10 \text { ). }\end{array}$ \\
\hline & $\begin{array}{l}\text { "General Design Criteria," } \\
\text { DOE Order } 6430.1 \mathrm{~A}\end{array}$ & $\begin{array}{l}\text { Wetlands shall be avoided or given } \\
\text { lowest priority when siting the } \\
\text { MLLWTF (Sectiv: } 4.2 .1 \text { ). }\end{array}$ \\
\hline
\end{tabular}


Table 4. MLLWTF environmental siting guidelines.

\begin{tabular}{|c|c|c|}
\hline Guideline category & Regulations/requirements & Guidelines \\
\hline $\begin{array}{l}\text { Archeological/ } \\
\text { historical }\end{array}$ & $\begin{array}{l}\text { DOE Advisory Council on } \\
\text { Historic Preservation; Idaho } \\
\text { State Historic Officer }\end{array}$ & $\begin{array}{l}\text { An archeological survey will need to } \\
\text { be performed on all candidate sites } \\
\text { (Section 3.3). }\end{array}$ \\
\hline $\begin{array}{l}\text { Geological } \\
\text { features- } \\
\text { geological } \\
\text { complexity }\end{array}$ & Best engineering judgement & $\begin{array}{l}\text { The ability of the site to be } \\
\text { characterized (i.e., not a complex } \\
\text { geological location) shall be } \\
\text { considered when siting the } \\
\text { MLLWTF. }\end{array}$ \\
\hline $\begin{array}{l}\text { Geological features- } \\
\text { ground slope }\end{array}$ & Best engineering judgement & $\begin{array}{l}\text { The slope of the land surface and } \\
\text { corresponding energy available for } \\
\text { erosion shall be considered when } \\
\text { siting the MLLWTF. }\end{array}$ \\
\hline $\begin{array}{l}\text { Geological } \\
\text { features- } \\
\text { volcanic exclusion } \\
\text { zones }\end{array}$ & Best engineering judgement & $\begin{array}{l}\text { The distance from volcanic exclusion } \\
\text { zones shall be considered when siting } \\
\text { the MLLWTF. }\end{array}$ \\
\hline $\begin{array}{l}\text { Remoteness from } \\
\text { site boundaries }\end{array}$ & Best engineering judgement & $\begin{array}{l}\text { Remoteness from site boundaries } \\
\text { shall be considered when siting the } \\
\text { MLLWTF. }\end{array}$ \\
\hline Endangered Species & $\begin{array}{l}\text { Endangered Species Act of } \\
1973 \text { (16 U.S.C.661 et seq.) }\end{array}$ & $\begin{array}{l}\text { An ecological survey will need to be } \\
\text { performed on all candidate sites, } \\
\text { along with a biological assessment } \\
\text { and consultation from the FWS, the } \\
\text { Idaho Fish and Game, and the BLM. }\end{array}$ \\
\hline
\end{tabular}


Table 5. MLLWTF strategic planning criteria.

\begin{tabular}{lll}
\hline Criteria area & Regulations/requirements & \multicolumn{1}{c}{ Criteria } \\
\hline $\begin{array}{l}\text { Effects on other } \\
\text { facilities }\end{array}$ & $\begin{array}{l}\text { "General Design Criteria," } \\
\text { DOE 6430.1A }\end{array}$ & $\begin{array}{l}\text { Sites that would adversely affect } \\
\text { operation of other facilities shall be } \\
\text { avoided (Section 4.2.7). }\end{array}$ \\
Land use & INEL Site Development Plan & $\begin{array}{l}\text { Avoid siting the MLLWTF on the } \\
\text { same site in active consideration for } \\
\text { other new facilities. }\end{array}$ \\
& Best Management Practice & $\begin{array}{l}\text { Consider the co-location of the } \\
\text { MLLWTF with other proposed } \\
\text { facilities at the INEL. }\end{array}$ \\
& Proposed EPA Regulations & $\begin{array}{l}\text { Carefully consider the location of the } \\
\text { MLLWTF relative to the position of } \\
\text { the Snake River Plain Aquifer } \\
\text { (Section 3). }\end{array}$ \\
& &
\end{tabular}

\subsection{Others}

It is desired to site the MLLWTF in compliance with the established INEL Site Development Plan, a document which outlines both near and long term land use strategies. This document was compiled in accordance with DOE Order 4320.1B and DOE-ID 10390. This includes, if practicable, sites chosen for near term new facilities (see Table 5). 


\section{SUMMARY AND CONCLUSIONS}

There are many laws and regulations, at Federal, State, and local levels, that address the siting of treatment, storage, and disposal facilities for hazardous, mixed, and low-level radioactive wastes. Adherence to these requirements assures the long-term protection of the environment.

The proposed MLLWTF will be sited within the $890 \mathrm{mi}^{2}$ encompassing the INEL. The site selection approach is illustrated in Figure 2. An advisory committee will make the final determination of "must" and "want" criteria, along with appropriate weighting factors. A field committee will use these criteria to rank potential siting choices. The NEPA process will assist in evaluation of the site alternatives, and final site approval will be obtained from the cognizant DOE operations office.

The following is a list of requirements applicable to the INEL for the location of the proposed MLLWTF, as determined from the requirements identified in this report.

- The MLLWTF cannot be located at a site below the 100 -year flood water elevation if the facility contains PCBs or PCB items with concentrations of $50 \mathrm{ppm}$ or greater (Section 3.8).

- If the MLLWTF does not store PCBs or PCB items but stores RCRA hazardous or mixed waste, it cannot be located in the 100-year floodplain unless it meets one of the three conditions discussed in Section 3.1.2.

- If the MLLWTF is located in Bingham, Bonneville, Clark, or Jefferson Counties, portions of the facility where treatment, storage, or disposal of hazardous waste will be conducted cannot be located within $61 \mathrm{~m}$ ( $200 \mathrm{ft}$ ) of a fault that has displaced during the last 10,000 years (Section 3.1.1).

- The MLLWTF cannot have any direct adverse impacts on sites listed or eligible for listing on the National Register of Historic Places (Section 3.3).

- The MLLWTF cannot be located within an endangered or threatened species critical habitat (Section 3.4).

- The MLLWTF cannot be located in a site such that air emissions from the facility will visibly impair any Class I air quality area (Section 3.9).

- The MLLWTF will be located so that the maximum calculated dose from exposure to internally deposited radioactive materials and/or radiation from external sources to offsite individuals shall not exceed the limits identified in Sections 4.1.1 and 3.13. 
- The MLLWTF cannot be located on a site traversed by buried pipe utilities unless it meets the requirements in Section 4.2.4.

- The MLLWTF cannot be located on a site that would adversely affect the operation of other facilities (Section 4.2.7).

- The location of existing RCRA and/or CERCLA sites shall be avoided (Section 4.1.1).

- The adequacy of existing or planned support and service facilities shall be considered (Section 4.1.1).

- $\quad$ The 500-year floodplain shall be avoided (Section 4.2.1).

- Wetlands shall be avoided (Section 3.10).

- $\quad$ Seismic zones shall be avoided (Section 4.2.2).

- $\quad$ The remoteness from site boundaries shall be considered (Section 6.9).

- The impacts of location above a sole-source aquifer shall be considered (Section 3).

- The effects of DOT regulations on the transport of waste to and from the MLLWTF shall be considered (Section 6.6)

- The slope of the land surface and corresponding energy available for erosion shall be considered (Section 7, Table 4).

- The distance from volcanic exclusion zones shall be considered (Section 7, Table 4).

- The commuting distance to the MLLWTF shall be considered (Section 6.9).

- The costs of installing new utilities and roads shall be considered (Section 6.9).

- The ability of the site to be fully characterized (i.e., not a complex geological location) shall be considered (Section 7, Table 4).

- The co-location of the MLLWTF with other proposed facilities at the INEL shall be considered (Section 7, Table 5).

Siting criteria and guidelines were developed for the MLLWTF through reviews of pertinent regulations and published guidelines. They are summarized in the following tables: 
- Table 1-MLLWTF cost criteria

- Table 2-MLLWTF service and support siting criteria

- Table 3-MLLWTF environmental siting criteria

- Table 4-MLLWTF environmental siting guidelines

- $\quad$ Table 5-MLLWTF strategic planning criteria. 


\section{REFERENCES}

Orr, B. R. and L. D. Cecil, 1991, Hydrological Conditions and Distribution of Selected Chemical Constituents in Water, Snake River Plain Aquifer, Idaho National Engineering Laboratory, 1986-1988, USGS Water Resources Investigation Report 91-4047, March 1991.

DOE (U.S. Department of Energy), 1991, Environmental Compliance Planning Monual at the Idaho National Engiroering Laboratory, DOE/ID 10166, April 1991.

Sivill, R. L., 1990a, Advanced Liquid Metal Reactor Site Selection Criteria Report, EGG-NPD-8837, January.

Sivill, R. L., 1990h, Reference Site Selection Report for the Advanced Liquid Metal Reactur at the IdGho National Engineering Laboralory, EGG-NPD-8836, March.

Spry, M. J., K. S. Moor, S. J. Maheras, and Y. K. Peterson, 1989, Site Selection Report for the New Production Reactor at the Idaho National Engineering Laborator;, EGG-NPR-8517, Rev. 1, July. 


\section{BIBLIOGRAPHY}

1. D. J. Kufen, Preliminary Siting Requirements for the Proposed Mixed and Low-Level Waste Disposal Facility at the INEL, EGG-WM-10155, March 1992.

2. D. J. Kufen, Preliminary Siting/Service and Support Criteria for the Proposed Idaho Waste Processing Facility at the Idaho National Engineering Laboratory, EGG-WMO-10303, June 1992.

3. EG\&G Idr .o, Inc., Environmental Manual.

4. M. J. Jorgenson-Waters, INEL Mixed and Low-Level Waste Treatment Facility Environmental Compliance Plan and Schedule, March 1992.

5. J. M. Hillary, Regulatory Siting Requirements for the Proposed Mixed and Low-Level Waste Disposal Faciiity at the INEL, EGG-WMO-10250, May 1992. 
Appendix A

\section{Definitions}




\section{Appendix A}

\section{Definitions}

\section{Bird Strike}

Airspace conflict between aircraft flight patterns and birds or waterfowl.

\section{Coastal Zone}

The coastal waters (including the lands therein and thereunder), strongly influenced by each other and in proximity to the shorelines of the several coastal states; includes islands, transitional and intertidal areas, sait marshes, wetlands, and beaches (16 U.S.C. 1453).

\section{Displacement}

The relative movement of any two sides of a fault measured in any direction ( 40 CFR 264.18).

Fault

A fracture along which rocks on one side have been displaced with respect to those on the other side (40 CFR 264.18).

\section{Holocene}

The most recent epoch of the Quaternary period, extending from the end of the Pleistocene to the present, i.e., during the last 10,000 years (40 CFR 264.18).

\section{Pleistocene}

An epoch of the Quaternary period, beginning two to three million years ago and lasting to the start of the Holocene.

\section{Polychlorinated Biphenyl (PCB)}

Any chemical substance that is limited to the biphenyl molecule that has been chlorinated to varying degrees, or any combination of substances that contains such substance ( 40 CFR 761.3). 


\section{PCB Item}

Any PCB article, article container, container, or equipment that deliberately or unintentionally contains or has a part of it any PCB or PCBs (40 CFR 761.3).

\section{Quaternary}

The second period of the Cenozoic era, following the Tertiary, beginning two to three million years ago and extending to the present.

\section{Vector}

An agent such as an insect, rodent, or the wind capable of mechanically or biologically transferring a pathogen from one location to another.

\section{Volcanic Exclusionary Zone}

Outside "recent" lava flows, at least $3 \mathrm{mi}$ from "older" vents, and at least 5 miles from "recent" vents (ALMR Site Selection Criteria Report).

\section{Washout}

The movement of hazardous waste from the active portion of the facility as a result of flooding (40 CFR 264.18).

\section{Wetland}

Land areas where the water table is at, near, or above the land surface long enough to promote the formation of hydric soils and to support the growth of hydrophytes.

\section{0-Year Flood}

A flood that has a one percent chance of being equalled or exceeded in any given year (40 CFR 264.18).

\section{0-Year Floodplain}

Any land area that is subject to a one percent chance of flooding in any given year from any source (40 CFR 264.18). 


\section{0-Year Flood}

A flood that has a 0.20 percent chance of being equalled or exceeded in any given year.

\section{0-Year Floodplain}

Any land area that is subject to a 0.20 percent chance of flooding in any given year from any source. 


\section{Appendix B}

Federal, Threatened, Endangered, and Candidate Species and State Species of Special Concern on the INEL 


\section{Appendix B}

\section{Federal Threatened, Endangered, and Candidate Species and State}

Species of Special Concern on the INEL

\begin{tabular}{|c|c|c|c|c|}
\hline \multicolumn{2}{|r|}{ Common name } & Scientific name & $\begin{array}{l}\text { Federal } \\
\text { status }^{a}\end{array}$ & $\begin{array}{l}\text { Etace } \\
\text { status }^{\text {a }}\end{array}$ \\
\hline \multicolumn{5}{|c|}{ Plants } \\
\hline \multicolumn{2}{|c|}{ Painted milk-vetch } & Astragalus ceramicus & $\mathrm{C} 2$ & NL \\
\hline \multicolumn{2}{|c|}{ Wooly pod milk-vetch } & Astragalus purshii & $\mathrm{C} 2$ & NL \\
\hline \multicolumn{2}{|c|}{ Oxytheca } & Oxytheca dendroidea ${ }^{b}$ & NL & SC \\
\hline \multicolumn{2}{|c|}{ Pincushion cactus } & Coryphantha missouriensis & NL & SC \\
\hline \multicolumn{2}{|c|}{ Large-flowered gymosteris } & Gymosteris nudicaulis & $\mathrm{NL}$ & SC \\
\hline \multicolumn{5}{|c|}{ Birds } \\
\hline \multicolumn{2}{|c|}{ Peregrine falcon } & Falco peregrinus & $\mathrm{E}$ & SC \\
\hline \multicolumn{2}{|c|}{ Merlin } & Falco columbarius & NL & SC \\
\hline \multicolumn{2}{|l|}{ Gyrfalcon } & Falco rusticolus & NL & SC \\
\hline \multicolumn{2}{|l|}{ Osprey } & Pandion haliaetus & NL & SC \\
\hline \multicolumn{2}{|c|}{ Baid eagle } & Haliaeetus leucocephalus & $\mathrm{E}$ & SC \\
\hline \multicolumn{2}{|c|}{ Swainson's hawk } & Buteo swainsoni & $\mathrm{C} 2$ & SC \\
\hline \multicolumn{2}{|c|}{ Ferruginous hawk } & Buteo regalis ${ }^{\mathrm{b}}$ & $\mathrm{C} 2$ & SC \\
\hline \multicolumn{2}{|c|}{ Burrowing owl } & Athene cunicularia ${ }^{b}$ & NL & SC \\
\hline \multicolumn{2}{|c|}{ White-faced ibis } & Plegadis chihi & NL & SC \\
\hline \multicolumn{2}{|c|}{ Long-billed curlew } & Numenius americanus & $\mathrm{C} 2$ & SC \\
\hline \multicolumn{5}{|c|}{ Mammals } \\
\hline \multirow{2}{*}{\multicolumn{2}{|c|}{$\begin{array}{l}\text { Townsend's western big-eared bat } \\
\text { Bobcat }\end{array}$}} & Plecotus townsendi & $\mathrm{C} 2$ & NL \\
\hline & & Lynx rufus ${ }^{b}$ & NL & SC \\
\hline \multicolumn{5}{|c|}{ a. Status Codes: } \\
\hline \multicolumn{5}{|c|}{$\begin{array}{l}=\quad \text { Category } 2 \text { species } \\
=\quad \text { Endangered species } \\
=\quad \text { Not listed } \\
=\quad \text { Species of special concern } \\
=\quad \text { Threatened species. }\end{array}$} \\
\hline \multicolumn{5}{|c|}{ b. Known to occur on the NPR site. } \\
\hline \multicolumn{5}{|c|}{ Source: Private communication, C. S. Staley to J. S. Irving, EG\&G Idaho, Inc. June 1989.} \\
\hline
\end{tabular}



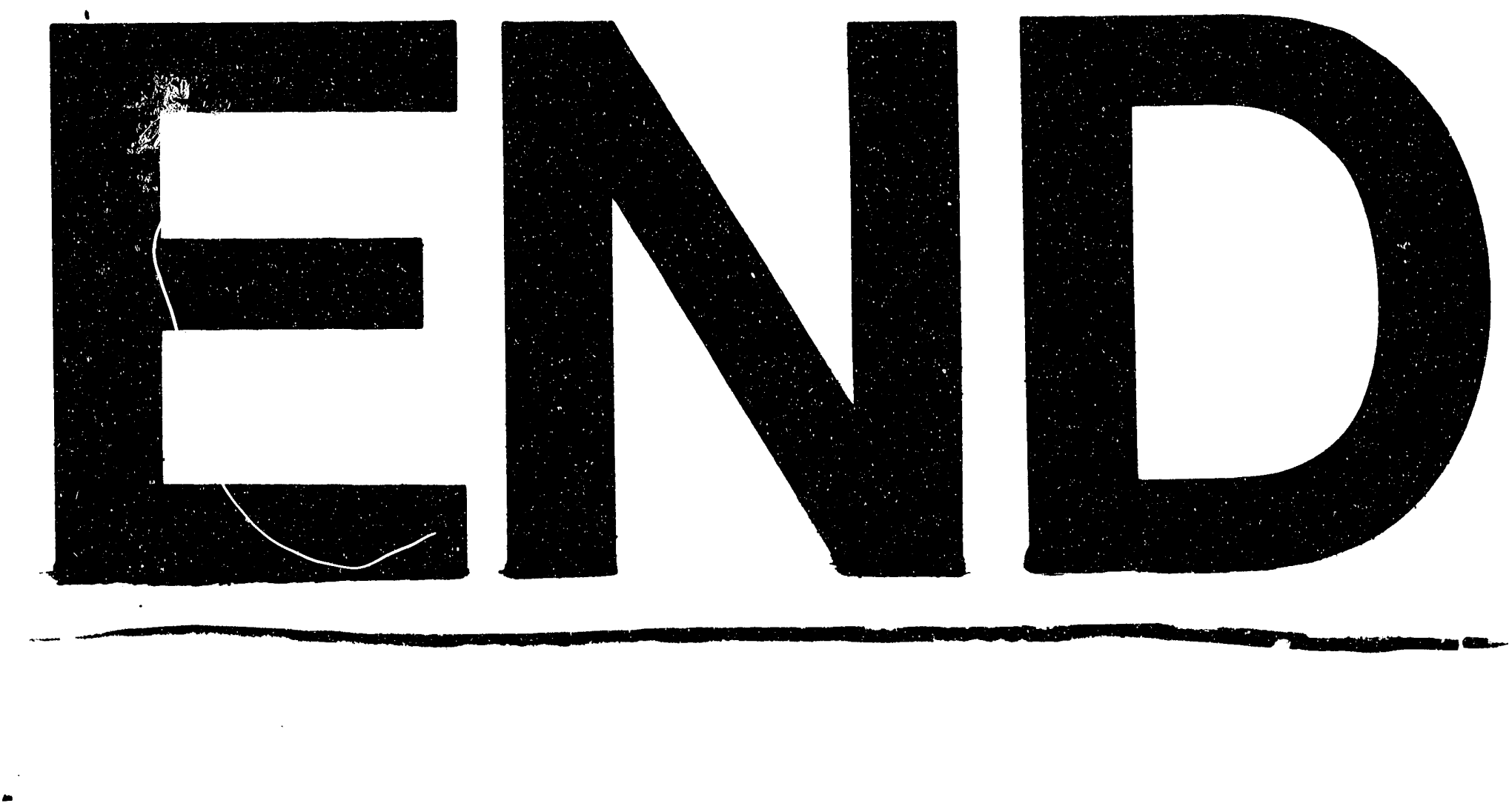

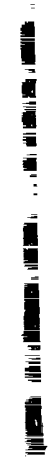
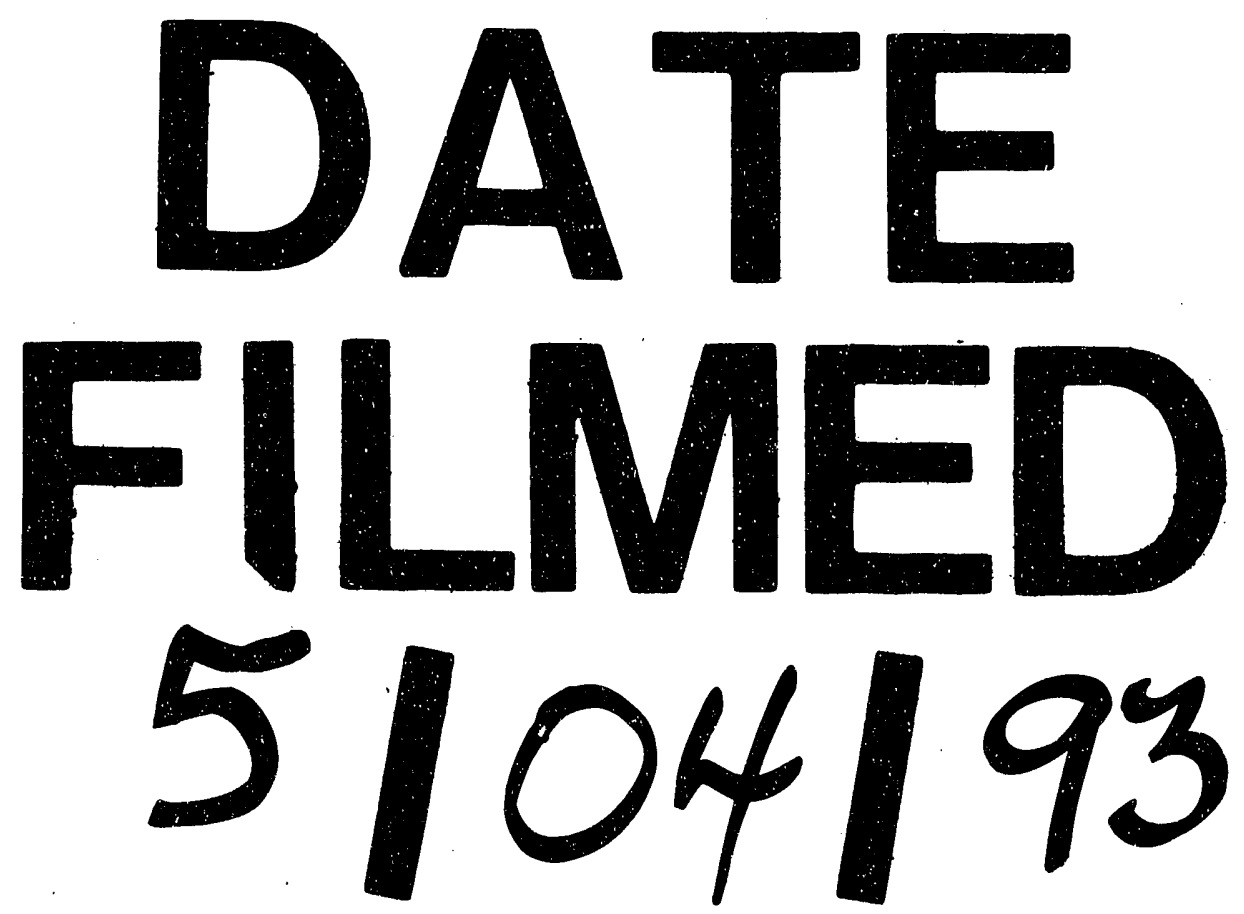
